\title{
Reading Past Cases of Child Cruelty in the Present: The Use of the Parental Right to Discipline in New Zealand Court Trials, 1890-1902
}

\author{
Debra Powell
}

In 2003 the United Nations Children's Fund (UNICEF) annual report on child welfare focused its concerns on the physical maltreatment of children, and published a league table of fatal child abuse statistics that placed New Zealand among the worst performing Organisation for Economic Cooperation and Development (OECD) nations. ${ }^{1}$ Among its recommendations was the ending of legal sanctions (as enshrined in section 59 of the New Zealand Crimes Act 1961) that allowed for the hitting of children in the name of discipline. ${ }^{2}$ Since that time, the topic of child punishment has generated significant anxiety and debate amongst child welfare advocates, doctors, educators, journalists, politicians and the general public. ${ }^{3}$ Jane and James Ritchie, psychologists from the University of Waikato in New Zealand, were the first to suggest a link between the country's high levels of societal and domestic violence and the physical disciplining of children. ${ }^{4}$ In 1979, acting on the findings of their groundbreaking study on the use of physical punishment in the home, the Ritchies made a submission to parliament advising 'the elimination from statute of any provision that permits the right to employ physical force in the correction and training of the young' ${ }^{5}$ Not only was their submission disregarded, but the response they encountered surprised them in its aggression - they had, by their own account, uncovered a firmly embedded 'cultural pattern' which, when threatened, provoked a strength of feeling 'so beyond reason and rationality as to indicate the social equivalent of a personal neurosis' ${ }^{6}$

\footnotetext{
1 UNICEF, 'A League Table of Child Maltreatment Deaths in Rich Nations', Innocenti Report Card Issue No. 5 (September 2003), Innocenti Research Centre, Florence, http://www.unicef-irc.org/publications/pdf/repcard5e. pdf accessed 14 May 2011. With Hungary, New Zealand's abuse fatalities were singled out as being six times higher than the average rate for the leading countries. Only Mexico and the United States rated higher.

2 Statutes of New Zealand, 1961, No. 43, Crimes Act, Section 59; Innocenti Report Card Issue No. 5, 22-28. The report identifies the hitting of children by parents or carers as the most common form of violence in the industrial world.

3 For a comprehensive timeline of events relating to child discipline laws see Beth Wood, Ian Hassall and George Hook, Unreasonable Force: New Zealand's Journey Towards Banning the Physical Punishment of Children (Wellington: Save the Children New Zealand, 2008), 33-50.

4 Jane and James Ritchie, Spare the Rod (Sydney: George Allen and Unwin, 1981), 105-22.

5 ibid., 132.

6 ibid., viii.
} 
In June 2007, however, the Ritchies' vision came to fruition with the passing of the Crimes (Substituted Section 59) Amendment Act, which effectively removed the defence of 'reasonable force' for the purpose of correction, for parents charged with assaulting their children. ${ }^{7}$ During the course of the 2007 campaign, those seeking the full repeal of Section 59 met with the same welter of intense emotion that the Ritchies had encountered almost 30 years earlier. ${ }^{8}$ It had become clear that the issue of child discipline was one that still 'cuts deep[ly] into the national psyche' ${ }^{9}$

While proponents of repeal positioned it as a necessary step towards developing a domestic culture of non-violence towards children, opponents focused their concerns more narrowly on the criminalisation of the disciplinary smack. ${ }^{10}$ The resulting debates, which were played out extensively in the public media, focused almost exclusively on the removal of the parental right to discipline their children as they choose. ${ }^{11}$ Among those who continue to believe in physical punishment as part of 'good parental behaviour', the resistance to change has been intense. ${ }^{12}$ The complex range of responses to repeal, however, belied the simplicity of its original aim: to remove the special legal defence available to parents who were prosecuted for significant assaults on their children, thereby affording children the same legal protection from physical assault as adults (or indeed, as animals). ${ }^{13}$ As the bill's sponsor, Green Party MP, Sue Bradford stated during its first reading:

\footnotetext{
7 With the 2007 amendment to s. 59 of the Crimes Act, New Zealand became the 18th country to revoke legal provisions allowing for the physical punishment of children.

8 The first reading of the bill called for full repeal by removing s. 59 from the statute books. Compromise led to amendment in the form of a convoluted rewording that nevertheless removes the parental right to strike a child for the purpose of correction.

9 Sue Bradford, 'Crimes (Abolition of Force as a Justification for Child Discipline) Amendment Bill', First Reading, Parliamentary Debates (Hansard), vol. 627, 22086, http://www.parliament.nz/en-NZ/PB/Debates/ Debates/b/1/6/47HansD_20050727_00001406-crimes-abolition-of-force-as-a-justification.htm accessed 27 April 2011.

10 Hence the popular terminology promulgated by the media who referred (and continue to refer) to the discourse surrounding the bill and subsequent amendment as the 'anti-smacking debate'.

11 British child welfare historian Harry Hendrick notes that the welfare of vulnerable children has more often been focused on adult, societal concerns, or, as Bronwyn Dalley says, on 'what adults consider children require, rather than children's needs' (Harry Hendrick, Child Welfare: England 1872-1989 (London and New York: Routledge, 1994), 257; Bronwyn Dalley, 'Deep and Dark Secrets: Government Responses to Child Abuse', Past Judgement: Social Policy in New Zealand History, eds, Bronwyn Dalley and Margaret Tennant (Otago University Press, 2004), 178).

12 The bill for the repeal of s. 59 received more public submissions than any other piece of legislation in New Zealand's history (Wood, Hassal and Hook, 8). Moreover, a well-funded but obfuscatory campaign by repeal opponents led to a national referendum in which 80 per cent of respondents (from a voter turnout of around 50 per cent) disagreed when asked whether 'a smack as part of good parental correction should be a criminal offence'.

13 'Crimes (Abolition of Force as a Justification for Child Discipline) Amendment Bill', First Reading. A related aim was to bring New Zealand law into line with the United Nations Convention on the Rights of the Child, which s. 59 effectively stood in breach of.
} 
I do not understand at all why it is illegal in New Zealand to beat my spouse, another adult, a policeman, or even an animal harshly with a horse crop or a piece of wood, but it can be legal to do the same thing to my child. It seems to me that section 59 of the Crimes Act is a relic of English nineteenth century law and thinking, which said that children were simply the property of their parents and were subject to their total control and to harsh physical discipline. At that time the same applied to wives, servants and horses. Strangely, it is only children to whom this quaint but dangerous law still applies. ${ }^{14}$

This chapter seeks to shed some light on the longer history of this 'quaint but dangerous' legislation by investigating its practice in the New Zealand courts at the turn of the twentieth century. Given the current strength of feeling, it is surprising that the laws relating to child discipline and child abuse have so far received little attention from New Zealand's social and legal historians. ${ }^{15}$ This chapter implicitly suggests that their investigation is crucial to our understanding of current debates, and the anxieties that surround them. In tracking the history and context of early child welfare legislation in the courts and in communities, this chapter reveals that late-nineteenth and early twentieth century contemporaries struggled similarly to negotiate the tensions between notions of parental control and parental abuse. It appears that attempts to balance the rights of parents to discipline and punish, and the need to legislate against parental violence and abuse have long been fraught with difficulties. To uncover the ways people imagined parental discipline and control, the chapter examines these issues using a microhistorical approach. This method, using the close reading of legal files from court trials and their media reportage, derives from social and cultural historical modes of analysis that are also relevant to legal-historical scholarship. I contend that the interpretation of historical court narratives might contribute fresh ways of seeing our present struggles over the place of physical punishment both within families and before the law.

The two case studies I have selected to illustrate this theme took place nine years apart. In 1893 Kate Donovan was charged under the Children's Protection Act 1890 with 'ill-treating' her son by beating him with a stock whip. ${ }^{16}$ In 1902 Harriet Drake was tried under the Criminal Code Act 1893 for the manslaughter of her daughter, who died following a 'severe beating' ${ }^{17}$ While vastly different in terms of charges and outcomes, and in the social classes of the accused, the case trials share similarities. Each involved extreme parental violence

14 ibid.

15 An important exception is Sally Maclean's research into the historical use of s. 59 in child cruelty cases tried in the Christchurch Courts (Sally Maclean, 'Child Cruelty or Reasonable Punishment? A Case Study of the Operation of the Law and the Courts 1883-1903', New Zealand Journal of History 40, no. 1 (2006): 7-24.

16 'Parental Castigation', Wanganui Chronicle, 19 September 1893, 2.

17 The King v Drake, Gazette Law Reports, Court of Appeal, 22 (1902), 145-49. 
perpetrated by a mother on an eight-year-old child. Both the accused women argued that their actions were carried out as part of good parental discipline and turned to the legal defence of reasonable force for the purposes of correction. Both trials relied heavily on evidential testimony provided by friends, family and community. Above all, these case trials illuminate the contradictions and tensions surrounding the emerging ideas of child abuse and child protection that could be discerned at social, legal and governmental levels.

Beginning with the first case, this chapter goes on to consider the significance of early legislative responses and the emergence of agencies concerned with the issue of child welfare. The investigation of the second case trial is followed by an exploration of the peculiar tensions borne from the need to prosecute against such abuses in what, I argue, was an innately violent society.

Kate Donovan, a deserted wife and mother, was reported to be the first to be charged under New Zealand's Children's Protection Act $1890 .{ }^{18}$ Those attending the Auckland Police Court trial in 1893 heard from neighbour, Ellen Clark, how she had witnessed eight-year-old Daniel being whipped and beaten so severely by his mother, that the sight of the boy's body 'nearly made her faint'. ${ }^{19}$ Attracted by the child's screams, Ellen had peered in through the windows of the house, attempted to force the locked door and threatened to 'call a policeman', while Daniel's older sister ran pleading for someone to stop her mother from killing the boy. ${ }^{20}$

In court Kate Donovan stated that she did not consider the whipping too severe, insisting that the boy had grossly misbehaved himself by 'interfering' with the five-year-old daughter of a neighbouring family. ${ }^{21}$ Daniel himself was called to testify before the court, and responded to the first line of questioning by declaring that 'he knew if he did not tell the truth he would go to burning fire' ${ }^{22}$ He told the court that his mother had beaten him for 'locking a little girl in her room', and doing 'naughty things to her', though he maintained that it had been his sister Mary who had locked them in the room and that he had been accused unfairly. ${ }^{23}$

Counsel for the defence, in an impassioned call to reason, attempted to shift the focus to the witness Ellen Clark, who, it was noted, had only lived alongside the defendant for one week. Was she in the habit of peering into people's windows? Had she never beaten her own little boy? The Bench, it was pointed out, frequently censured parents for not controlling their children,

18 'Parental Castigation', 2.

19 'A Terrible State of Things', Observer (Auckland), 16 September 1893, 3.

20 ibid., and 'People are not Satisfied', Observer (Auckland), 21 October 1893, 2.

21 'Parental Castigation', 2.

22 ibid.

23 ibid. 
yet, 'unfortunately there were persons who would try to interfere with parents when they tried to control their children. The question was: what were parents to do?'. ${ }^{24}$

The magistrate himself physically examined Daniel and found that his body was 'covered with wales' and that the child 'could hardly turn his head'. ${ }^{25}$ Nonetheless, he admitted to finding himself in 'a difficult position' as Kate was a deserted wife with sole care of her children and reliant on outdoor relief in the form of Charitable Aid. Moreover, he personally took no issue with the use of a whip as punishment for the boy's alleged misdeeds and 'fully agree[d] that children must be controlled' ${ }^{26}$ On the question of whether the punishment was 'reasonable' under the circumstances, the magistrate, however, declared himself to be of the opinion that the 'the boy had been punished too severely for his tender years'. Kate Donovan was found guilty of ill-treating her son. She was fined 40 shillings and returned home with Daniel in tow. ${ }^{27}$

Four weeks later, Daniel's name again turned up in the official records, this time in a coronial report. The post-mortem carried out on Daniel's body showed that his sudden death had been caused by a fracture of the skull. ${ }^{28}$ The inquest, which took place at the bar of the Rob Roy Hotel in Freemans Bay, heard a confusion of testimonies in which Daniel's mother, neighbours, and other witnesses told conflicting stories. The boy had eaten poisoned oranges, or had fallen and hit his head on a fence; he spent the morning at school with his sister, or else he spent it lying on a stranger's couch bleeding from a headwound. ${ }^{29}$ Letters to the editor of the Auckland Observer suggest that there was a degree of unease among those familiar with the case, and at least one writer was prepared to suggest a connection between the boy's violent, sudden death and the ongoing violence in the Donovan household. ${ }^{30}$ Such concerns appear to have been put to one side at the coroner's inquest. Instead, those attending heard from neighbours like Annie Melrose who came forward to offer positive accounts of Kate's maternal character. Annie deposed that she had 'always found [Mrs Donovan] kind and affectionate towards her children and only beat them when they were naughty', and added in reference to the earlier indictment for child cruelty, that '[h]er whole affair was only a bit of spite' ${ }^{31}$ Despite claiming to be 'dissatisfied' with the variously opposing points of evidence, the coroner's

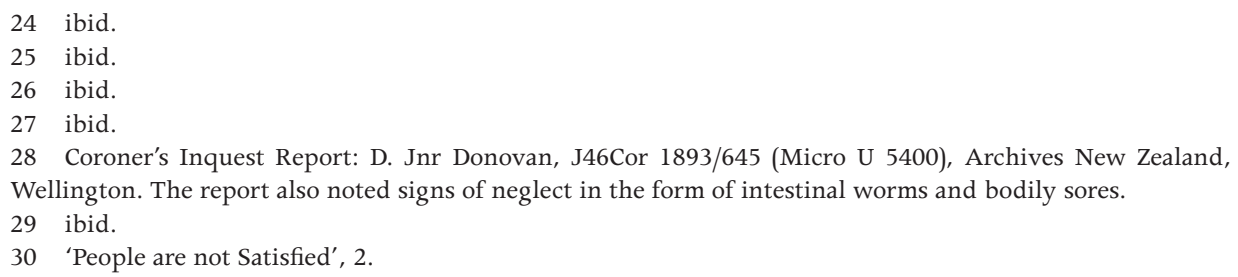


jury gave Kate Donovan the benefit of the doubt. They found that 'no evidence was forthcoming to show how the fracture was caused', and an open verdict was brought in on Daniel's death. ${ }^{32}$

Daniel Donovan's story, inconclusive and open-ended as it is, nevertheless illustrates something of the tensions between notions of 'parental guidance' and the reality of physical violence, and highlights the significant challenges encountered by a society grappling with rapidly changing attitudes around the care and welfare of children. These changing ideals were driven by a 'reconceptualisation' of the notion of childhood, which took place throughout the western world from around the mid-to late-nineteenth century. ${ }^{33}$ While the rising awareness of children's issues informed child welfare policy and practice in New Zealand, the path between shifting ideologies and legislative change was not always direct. In England, an obvious need for child protection legislation had been uncovered by reformers associated with child welfare organisations such as the National Society for the Prevention of Cruelty to Children, and England's Prevention of Cruelty to, and Protection of, Children Act, which was introduced there in 1889, came about as a result of the long and concerted efforts of those associated with the Society. ${ }^{34}$ In New Zealand, however, there had been no such agitation for reform. Isolated concerns about parental violence or mistreatment were muted and, before the turn of the century, passed largely without comment. New Zealand legislation, enacted in 1890, just one year after the introduction of the English act, was, in the words of New Zealand government minister the Hon. Dr Pollen, 'simply a copy of [the] statute which had been passed by the Imperial Legislature in its last session' ${ }^{35}$ The honourable minister argued against the 'slavish' adoption of such measures when 'there was no necessity, to his mind, for encumbering our statute-book, which was already greatly over laden with laws that could have no immediate beneficial operation'. For Pollen and others, the object of the Act, which was 'the prevention of cruelty to and better protection of children', was an extraneous issue as 'the conditions

\footnotetext{
32 ibid.

33 The awareness of children's issues took place across a range of Western countries. Paris held the first international conference on child welfare in 1882 and, in that same year, the state of Massachusetts pioneered a law to protect children from cruelty and neglect. A second conference, which was held in Florence in 1896, was the catalyst for the formation of the International Congress for the Welfare and Protection of Children (Lionel Rose, The Erosion of Childhood: Child Oppression in Britain 1860-1918 (London and New York: Routledge, 1991), 235). On the shift in ontological thought around child life see for instance, Hendrick, 21-37; George Behlmer, Child Abuse and Moral Reform in England 1870-1908 (Stanford University Press, 1982), 44-77; Viviana Zelizer, Pricing the Priceless Child: The Changing Social Value of Children (New York: Basic Books, 1985), 11; and Dorothy Scott and Shurlee Swain, Confronting Cruelty: Historical Perspectives on Child Protection in Australia (Melbourne University Press, 2002), 9-10.

34 Behlmer gives a detailed account of the origins and passage of the English Children's Protection Act, commonly known as the 'Children's Charter', in Child Abuse and Moral Reform, pp.78-119.

35 Children's Protection Bill, New Zealand Parliamentary Debates, vol. 97, 3 July 1890, 260-61.
} 
for which the act was intended to provide had practically no existence in this colony at all'. ${ }^{36}$ However, it was unanimously agreed that it was 'better to prevent evil from asserting itself than to attempt to cure it after it had arisen' ${ }^{37}$

Those looking to official figures might be forgiven for coming to such conclusions: even in the wake of a severe depression in the economy in the 1880 s and 1890s, few cases of child cruelty came to official notice. Under the terms of New Zealand's Children's Protection Act 1890, intentional ill-treatment or neglect of a child was punishable by a fine of up to one $£ 100$ or up to two years imprisonment, and a magistrate could order the removal of a child or children from the family home. ${ }^{38}$ While these provisions nominally included 'any offence involving bodily injury to the child', enshrined within the Act was the common law defence of 'reasonable punishment'. ${ }^{39}$ Section 14 held that: 'Nothing in this Act contained shall be construed to take away or affect the right of any parent, teacher, or other person having the lawful control or charge of a child to administer reasonable punishment to such child' ${ }^{40}$

As this chapter shows, the practice of physically striking a child to cause shock and pain as punishment, and the belief in its necessity and efficacy, was firmly entrenched in Pākehā (non-Māori) society, and therefore the boundaries of what might be considered 'reasonable punishment' proved slippery to define. ${ }^{41}$ As a corollary the law was never heavily enforced. Indeed, in the eight years between 1892 (when the annual police reports began recording returns) and 1901, only 35 cases of child cruelty or neglect had been tried in New Zealand's courts of law. ${ }^{42}$

Despite government assertions that New Zealand children were not yet in need of protection, societies and agencies concerned with the welfare of vulnerable children were formed in the larger urban centres, and were kept extremely busy

\footnotetext{
36 ibid.

37 ibid.

38 Statutes of New Zealand, 1890, no. 21, Children's Protection Act, ss. 3 and 7, 78, 80. Before the 1890 Act, child cruelty cases involving violence were charged under the Crimes Act 1867 as assault, assault causing grievous bodily harm or assault causing actual bodily harm.

39 Children's Protection Act, Section 79(a), 80.

40 Children's Protection Act, s. 14, 83. This same provision could also be called on for those charged with the assault of a child under the 1893 Criminal Code Act (s. 68). The defence of reasonable parental punishment was carried over into the 1908 Crimes Act (s. 85), and repeated with minor amendments in s. 59 of the 1961 Crimes Act.

41 The research carried out by the Ritchies in the 1960s and 1970s showed smacking to be the prevalent disciplinary method, with just over half of parents surveyed reporting that they hit their child once a week or more (Ritchie, 27). Figures from a more recent study suggest this figure may have been conservative. A 2006 study by the Dunedin Health and Development Research Unit found that 71 per cent of a sample group of 26-year-olds experienced physical punishment on a regular basis throughout their childhoods. Jane Millichamp, Judy Martin and John Langley, 'On the Receiving End: Young Adults Describe their Parents' Use of Physical Punishment and other Disciplinary Measures during Childhood', Journal of the New Zealand Medical Association 119, no. 1228 (27 January 2006), http://www.nzma.org.nz/journal/119-1228/1818/ accessed online 12 May 2011.

42 Maclean, 10-11. Maclean notes, as do historians transnationally, that trials were more likely to focus on neglect than abuse, as 'cruelty was more difficult to define and reach a consensus on'. See also Hendrik, 30-31.
} 
in their work among families. Throughout the 1890s, Societies for the Protection of Women and Children (or the SPWC) were established in Auckland, Wellington and Dunedin, and the Children's Aid Society was founded in Christchurch. ${ }^{43}$ The SPWC employed 'lady visitors' working in semi-professional positions to call into the homes of the poor to assess their needs. The group focused their efforts primarily on the work of 'compelling husbands and fathers to recognise and discharge their duties', which essentially meant following up cases of unpaid maintenance for deserted women and children. ${ }^{44}$ Nevertheless, some attempts were made to address the problems of child neglect and domestic violence when incidences were brought to their attention. The process by which concerned citizens could report such incidences was explained in Otago's Daily Times:

Every case brought under the notice of the Society is investigated by the chairman, who is in attendance at a certain place one hour every day for that purpose. Having investigated a case he decides what steps should be taken with regard to it. As a rule, a letter from the secretary is sufficient to produce the desired effect; but when necessary the Society has recourse to the law. ${ }^{45}$

It was understood that communities regulated and kept watch over their own members and, while a number of cases were reported to local societies by the police, it was expected that incidences of abuse or neglect would be identified and reported by individuals living within neighbourhoods:

No active steps are taken by the committee to find out such cases as the Society deals with. The mere knowledge of the fact that a society exists for the protection of women and children causes people outside of it to bring cases under its notice. ${ }^{46}$

And, to some extent, this strategy was successful. In 1900 in the Coromandel district, northwest of Auckland, a local doctor reported such a case to the Auckland SPWC after local police declined to take action against Alfred Elmore for the excessive 'punishment' of seven-year-old Thomas Johnstone, who was in his charge. ${ }^{47}$ Although Elmore received a paltry $£ 2$ fine for his acts, the efforts of the SPWC in taking the case to court were rewarded by the public discussion that followed about the frequency and levels of violence used to punish children. Figure 1 shows a journalistic representation of the case, which was published for the readers of the Auckland Observer. The narrative describes the judicial leniency in this case as 'an outrage in the name of justice' and goes on to illustrate the unease that this case generated among local residents in the Coromandel community.

\footnotetext{
43 Maclean, 21.

44 'Society for the Protection of Women and Children', Otago Daily Times, 11 February 1899, 8.

45 'Society for the Protection of Women and Children', Otago Daily Times, 13 February 1899, 3. 46 ibid.

47 'A Fiendish Story: How Children are Treated at Coromandel', New Zealand Freelance, 18 August 1900, 6.
} 


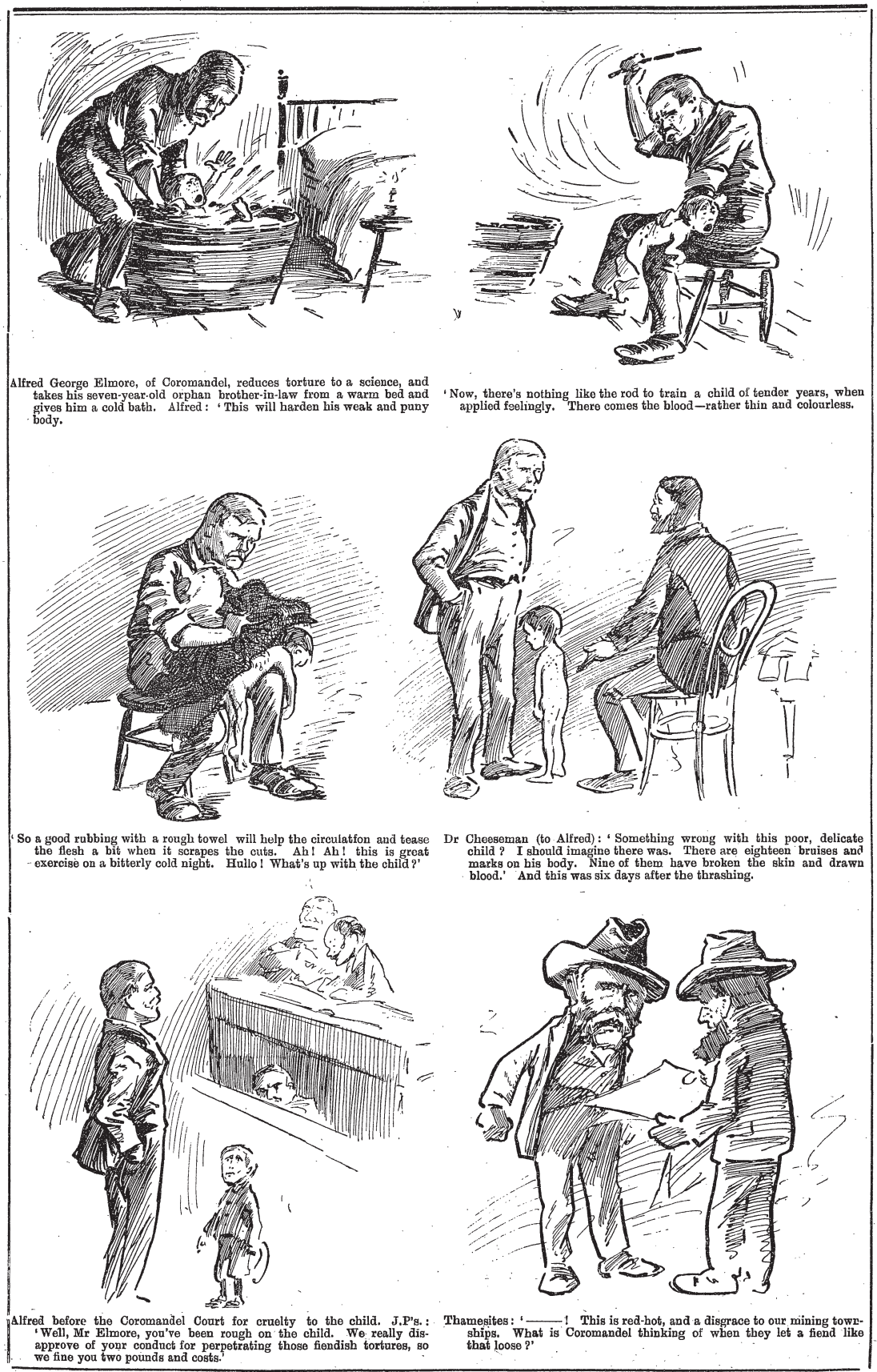

A GROSS SCANDAL:-THE SCIENCE OF TORTURE.

A SOANDAL AND AN OUTRAGE ON THE NAME OF JUSTIOE.

Figure 1: The Auckland Observer comments on the judicial leniency afforded to Alfred Elmore after excessively 'disciplining' seven-year-old relative Thomas Johnstone ('A Gross Scandal - The Science of Torture', Observer, 18 August 1900, 20). 
Such media commentary, however, was extremely uncommon and the scarcity of reportage or observation on the issue of child cruelty suggests that public discussions about the vulnerability of children were measured and infrequent. The physical welfare of children in their own homes was an issue that remained heavily veiled by powerful social conventions, which prevented interference into the private sphere of families and into the parent-child relationship in particular. Despite the confidence of the SPWC that incidences of cruelty would be 'brought to their attention', it is clear that cases like that of Thomas Johnstone were among only a small minority of instances of child neglect or abuse that were actually reported to social agencies or legal authorities. Witness testimonies taken from events that resulted in prosecutions commonly reveal evidence of prior or ongoing neglect or violence, and a marked reluctance by neighbours to involve those outside of the immediate community context. The Donovan trial provides evidence that those living within communities who did intervene when they believed the line between chastisement and cruelty was crossed, risked public censure. Moreover, neighbour Ellen Clark testified in court that she had witnessed Daniel being beaten more than once in the week that she had lived in Freemans Bay - it might be presumed, then, that others were aware of ongoing violence in the Donovan household, yet only one other person from the Freemans Bay community was prepared to serve as a witness against Daniel's mother in a court of law. ${ }^{48}$ While a measure of self-policing certainly did take place in New Zealand communities, evidence from trial records detailing cases of fatal violence suggests that individuals struggled, and at times failed, to address long-standing and extreme cases of abuse occurring within their neighbourhoods.

Popular understandings of the root causes of child neglect and cruelty, and just where such problems might be found, further veiled abuse occurring within families. While such issues were widely believed to have been problems of the poor, those working in the area of child protection had come to recognise children's vulnerability across class boundaries. George Behlmer notes that the London Society for the Prevention of Cruelty to Children argued strongly that child cruelty was 'unrelated to economic status' ${ }^{49}$ Representatives of Scotland's equivalent society, the Royal Scottish Society for the Prevention of Cruelty to Children, agreed, declaring that they 'wished the Society had the right to investigate the homes of the better classes as well as the homes of the poor, as they might often find cases which surprise them very much'. ${ }^{50}$ The New Zealand trial of Harriet Drake, who, in 1902, was indicted for the manslaughter

48 Maclean's study of child abuse trials processed in the South Island courts between 1883 and 1903, similarly found that 'much child abuse went unreported or was not prosecuted', Maclean, 11.

49 Behlmer, 94.

50 Lynn Abrams, The Orphan Country: Children of Scotland's Broken Homes from 1845 to the Present Day (Edinburgh: John Donald, 1998), 210. 
of her eight-year-old daughter Dorothy, may have been seen as a case in point. The weight of the medical evidence in this case, coupled with the fact that the woman accused of manslaughter was the matriarch of a 'well-known and highly-respected' middle-class family, attracted considerable public interest in the trial. ${ }^{51}$ Unlike Daniel Donovan's case, there was little ambiguity surrounding the death of Dorothy Drake. The description of the injuries on the child's body left few in doubt that she had died of 'shock' after being 'disciplined' by her mother and two older sisters. ${ }^{52}$ Dorothy's punishment, allegedly given after the child's refusal to recite a verse of poetry, was administered with a supplejack and a triple-lashed riding whip and appeared to have taken place systematically over the course of an afternoon. ${ }^{53}$ A post-mortem report left no doubt as to the viciousness of the assault on the child, noting that the extent of the bruising meant that a piece of unbruised skin as wide as a shilling could not be found. A deep depression on the right side of the child's head carried the marks of the metal handle of the whip and the inside of the scalp showed extensive bruising. Of note was the existence of old wounds and scars consistent with ongoing beatings. ${ }^{54}$

As a manslaughter case, Harriet was tried under the 1893 Criminal Code Act, and her defence relied almost exclusively on the parental right to reasonable force. ${ }^{55}$ Section 68 of the Act reads:

Section 68 (1) It is lawful for every parent or person in the place of a parent, or schoolmaster to use force by way of correction towards any child or pupil under his care; Provided that such force is reasonable under the circumstances; ... (3) The reasonableness of the force used, or of the grounds on which such force was believed to be necessary, shall be a question of fact and not of law. ${ }^{56}$

Dressed throughout the proceedings in deep mourning, Harriet argued that her actions were those of any responsible and loving mother - Dorothy had been a stubborn and disobedient child and in need of parental correction. The prosecution presented evidence, however, to show that Harriet was motivated by malice towards Dorothy that had existed since her birth. Witnesses were produced who were willing to attest to ongoing neglect and cruelty on the part

51 'Evidence at the Inquest', Evening Post (Wellington), 30 June 1902, 2.

52 Coroner's Inquest Report: Dorothy Drake, J46Cor 1902/456-829 (Micro U 5426), Archives New Zealand, Wellington. Harriet Drake's defence counsel's suggestions that Dorothy's death may have been due to concussion from an earlier fall, or even haemophilia, were unable to gain traction in the face of Harriet's admission that she had given the child 'a severe thrashing'. Evening Post (Wellington), 16 August 1902, 5.

53 ibid.

54 ibid.

55 Statutes of New Zealand 1893, Number 56, Criminal Code Act (s. 68).

56 Criminal Code Act 1893 (s. 68). This section was replicated with some slight rewording in s. 59 of the Crimes Act 1961, and remained in place for parents prosecuted for assault on their children until the 2007 amendment. 
of Harriet towards her daughter. ${ }^{57}$ Notably, these witnesses were outsiders, who were no longer immediately associated with the local community of Otaki an ex-domestic servant; a sister-in-law from Eltham who had fostered Dorothy for two and a half years; and an ex-labourer on the Drake family farm. From among those within the community, however, there was a markedly different response. A long line-up of defence witnesses from the Otaki district attested to the respectability of the Drake family and to Harriet's affection for her children and devotion to her domestic duties. ${ }^{58}$ Harriet's husband, Arthur, stood by his wife resolutely, insisting that: 'a warmer-hearted or more self-sacrificing woman there could not be ... she was entirely devoted to her household, and lived solely for the benefit of the children, who were very fond of her' ${ }^{\prime}{ }^{59}$

Harriet's defence counsel, Mr Skerret, spoke at length on the temperament and upbringing of the accused woman, and stressed that while the consequences of her act were shocking, it could not be suggested that they were intended or contemplated..$^{60}$ The act itself, he argued, was not one of deliberate or designed cruelty, but occurred in an outburst of passion. He appealed for mercy for 'a woman who had brought up her children in a creditable manner, and discharged her duty as a loving mother, and whose remaining seven children should not be left without a mother's loving attention and devotion' ${ }^{61}$ Given the evidence of the physical injuries detailed in the coroner's report and Harriet's own admission that she had beaten her daughter severely, it is unsurprising that she was found guilty of the manslaughter of her child. Mr Skerret's appeals in Harriet's defence did not, however, fall on deaf ears. The jury delivered their verdict with a unanimous recommendation to mercy in order to indicate to the judge their preference for a light sentence. Nevertheless, the sentencing judge, Justice Edwards, was pragmatic. He informed the court that, ' $[\mathrm{t}]$ hose who give way to their passions and allow themselves to use unrestrained violence towards young children must learn that the punishment which will follow will be a severe one' ${ }^{62}$ Harriet Drake was sentenced to six years with hard labour in Wellington's Terrace Gaol.

Undaunted, Harriet's defence counsel called for the case to go before a Court of Appeal. Mr Skerret argued that the prosecution's use of evidence relating to the mother's prior attitude towards the child had been both irrelevant and prejudicial. ${ }^{63}$ He contended that 'it had been established by the evidence already adduced by the Crown, that the occasion was a reasonable and proper occasion

57 'Charge of Manslaughter', Evening Post, 15 August 1902, 5.

58 'The Case for the Prosecution Closed', Evening Post, 16 August 1902, 5.

59 'The Drake Manslaughter Case: A Severe Sentence', Evening Post, 9 December 1902, 5.

60 ibid.

61 ibid.

62 ibid.

63 The King v Drake, Gazette Law Reports, Court of Appeal, 22 (1902), 145. 
for parental correction; that the only questions for the consideration of the jury was whether the punishment was excessive, and whether, if excessive, it had caused death, or had caused actual bodily harm' ${ }^{64}$ In deciding the question of what is meant by 'force reasonable under the circumstances' in such a case, $\mathrm{Mr}$ Skerret felt strongly that all argument must refer solely to the occasion of the correction. ${ }^{65}$ It was on this basis that the case was brought before the appeal judges. The parameters of what might constitute 'reasonable' force remained vague, however, and particularly so as they were to be considered in the context of the middle-class family home. When explaining his decision to allow the contested evidence, Justice Edwards demonstrated a keen awareness of this fact by repositioning his stance within the framework of a less emotive set of circumstances. He asked his fellow Court of Appeal judges to consider this:

If, for instance, a lad of seventeen, a scholar at a public school, should deliberately set himself to destroy the discipline of the school, and, after repeated mild punishments and kindly warnings, should be guilty of a further act of insubordination, it is plain that the schoolmaster would be justified in inflicting - nay, that in the interest of the offender himself he ought to inflict - a much more severe punishment in respect of such an act of insubordination than would be reasonable if such act stood alone. ... Under such circumstances ... it would be impossible to exclude evidence of the prior acts which rendered a severe punishment 'reasonable under the circumstances'. So, if a high spirited boy had fallen under the displeasure of his schoolmaster, and had been wilfully goaded into acts of insubordination ... and the schoolmaster availed himself of such an act of insubordination as an excuse for administering a flogging to the boy, it would, I think, be impossible to reject evidence as to the prior matters, which would establish that the motive ... was not the maintenance of discipline, but was the gratification of private malice. ... The use of force by way of correction by a parent stands in exactly the same position. ${ }^{66}$

While the circumstances of the case in question presented an altogether more complex picture, the Court of Appeal judges unanimously agreed in principle with Justice Edward's argument. They found that the testimony of Crown witnesses demonstrated that 'what was done was not honestly done by way of correction at all, but was done vindictively, and that the pretence that it was done for the purpose of correction was merely colourable' ${ }^{67}$ If, as Justice Williams pointed out, 'the mother was animated by dislike' and 'took the

64 ibid.

65 ibid., 146.

66 ibid., 149.

67 ibid., 147. 
occasion of a slight offence to cruelly beat [the child], then the force would not have been honestly used for the purpose of correction, and the defence must fail'. What the appeal judges had actually accomplished was a shift in focus which allowed them to avoid a debate about the 'reasonableness' of the parental force used to 'discipline' an eight-year-old child who had died as a result. In reopening the question of whether the force used had actually been carried out as part of parental correction, and by dismissing the appeal on that point, recourse to the second arm of the defence (whether the force used was reasonable) became unnecessary. Harriet's conviction was left to stand. ${ }^{68}$

If the definitions of cruelty proved difficult to define in such case trials, this was grounded in their taking place within a culture of violence that existed despite the claims of parliamentarians. A deep contradiction lay behind the system whereby the courts themselves sentenced parents under the Child Protection Act and the Criminal Code Act for the use of excessive violence towards their children, while simultaneously rebuking others for failing to control their wayward offspring. Judges regularly commented on the need for physical punishment to be carried out by parents to stem the flow of delinquent children being brought before them. Indeed, those who were guilty of the 'evils of laxity of home discipline' were said to be culpable of 'a crime against their children' ${ }^{69}$ On sentencing 14-year-old Martin Murphy for the indecent assault of an eight-year-old girl, in 1900, Justice Denniston commented that if all boys and girls of that age who committed indecency were brought up [before the court] they would have their docks full'. ${ }^{70}$ 'It was a pity', he said, 'to see so young a lad convicted'. In the judge's opinion, it should have been, 'another case for domestic discipline ... a sound thrashing by the boy's father would have been the commonsense solution of the case'.$^{71}$

The law further encouraged and promoted physical punishment by sentencing children to be flogged or birched by the police. The Criminal Code Act 1893 gave no minimum age for physical punishment using the birch or whip, and flogging using a cat-o'-nine-tails could be carried out from around the age of $16 .{ }^{72}$ On sentencing 15-year-old James McLaren in 1888, a Dunedin judge mused: 'It is difficult to know whether a boy of this age ought to be flogged with the "cat" ... a good birching cannot hurt; it will inflict pain but it cannot be suggested

68 ibid.

69 'Juvenile Depravity', Hawkes Bay Herald, 27 February 1889, 2.

70 'Supreme Court', Timaru Herald, 7 February 1900, 3.

71 ibid.

72 New Zealand Statutes 1893, no. 56, Criminal Code Act, s. 14, 325-26. Newspapers carry reports of judicially sanctioned corporal punishment being carried out on very young children. For example, in 1875 , a Thames court sentenced eight-year-old John Quadri to be privately whipped and incarcerated for 24 hours in the local prison after he was found guilty of stealing a fowl 'to the value of two shillings' ('This Day', Thames Star, 17 December 1875, 2). Judicial flogging was finally abolished in New Zealand with the Crimes Amendment Act 1941. 
there is any cruelty about it' ${ }^{73}$ This was certainly not the opinion expressed in a 1937 article in the British Medical Journal, where a medical doctor condemned the punishment - in which a boy was stripped, then tied hand and foot to a tripod and beaten with a heavy bundle of birch twigs soaked in brine as inhuman and barbaric. ${ }^{74}$ By English law, police surgeons were required to be on hand to check the condition of the heart between each stroke of the birch, and to administer treatment afterwards, and it was noted that it would require 'around three days' for a child to be fit to attend school following such a punishment. ${ }^{75}$ Accounts of judicial birching in New Zealand suggest that the experience diverged in severity and application and was subject to significant regional variation. ${ }^{76}$ A correspondent in the Wanganui Chronicle described the 'instrument of punishment' used in the judicial flogging of boys in Wellington as a rod of 'blood-curdling' appearence, which had been 'purposely split for about half its length into a number of tails, and is there bound with cord to prevent it splitting further, the tails being bound also at the ends' ${ }^{77}$ Obviously disturbed by the brutality of the practice, he went on to describe 'the case of a boy who was beaten so severely [by the instrument] his screams could be heard from the closed cell by the watch-house (where the "birching" was inflicted) to the other side of Lambton Quay' ${ }^{78}$

Predictably though, newspaper accounts of incidences of larrikinism and youth crime were regularly accompanied by correspondence from concerned citizens insisting on the 'healthy and stimulating laying on of birch and leather' to combat the 'rising problem' of moral laxity among the youth of the day. ${ }^{79}$ The view appears to have been widely held that '[i]f parents so neglect their children as to allow them to become a menace to the well-being of society, then the State must in self-defence take charge of those children and endeavour to fill the place of parents' ${ }^{80}$ Such correspondents may have gained a measure of satisfaction from an 1895 ruling, where fatherless Thomas Thompson was spared a conviction by the judge who declared that if someone from the boy's neighbourhood would whip him with 'ten good strokes of the birch', the offence would be expiated. A newspaper article describes how a volunteer from the

\footnotetext{
73 'Supreme Court', Otago Daily Times, 12 April 1888, 2. McLaren was sentenced to six months imprisonment with hard labour, and privately whipped with 20 strokes of the birch rod.

74 'The Birching of Children', British Medical Journal (20 March 1937): 618-19.

75 ibid.

76 See John A. Lee's autobiographical account of his childhood experiences of judicial flogging in latenineteenth century Dunedin (John A. Lee, The Children of the Poor (Christchurch: Whitcoulls, 1973), 231-33).

77 'Juvenile Offenders', Wanganui Chronicle, 1 May 1913, 5.

78 ibid.

79 'Juvenile Probation', New Zealand Truth, 27 January 1923, 4. See also 'Juvenile Depravity', Hawkes Bay Herald, 27 February 1889, 2.

80 'Juvenile Depravity', 2.
} 
neighbourhood agreed, 'amid roars of laughter from a crowded court' ${ }^{81}$ Such evidence puts the hesitancy of juries and judges to condemn parental abuse, when presented in the guise of discipline, in a clearer light.

Historians of child protection legislation have shown how fledgling governmental concern for neglected and vulnerable children in the nineteenth century was effectively deflected by a social focus on the delinquent and criminal child ${ }^{82}$ A dualistic view of children as both victim and threat influenced legislation enacted throughout western countries and, in New Zealand as elsewhere, any government apprehension concerning the problem of parental neglect or cruelty centred not on the problematic family, but was projected outward, to the threat to societal stability that unsupervised and undisciplined children might engender. ${ }^{83}$ In New Zealand, the passage of the Children's Protection Act 1890 promised to prevent cruelty and 'better protect' children, however, the need to protect the rights of children to bodily safety was effectively trumped by the need to protect the rights of parents to physically punish. Trial records demonstrate that the violent actions of parents who appeared before the courts of law on charges of 'cruelty' were never trivial, and significant physical injuries to children were not uncommon in such cases. Nevertheless, as Sally Maclean has shown, there was a great deal of inconsistency in the verdicts pronounced on those tried for the maltreatment of children. ${ }^{84}$ The two hearings considered here, one tried under the Children's Protection Act 1890 and the other under the Criminal Code Act 1893, resulted in convictions, though neither demonstrates an uncomplicated evaluation or understanding of the criminal actions under consideration. Rather, they provide evidence of complexity and uncertainty, as judges, juries and community members struggled to come to terms with the meanings of 'violence', 'discipline', 'reasonableness' and the boundaries of parental 'force'.

The events discussed in this chapter took place during a period of social and political flux, when emerging ideologies surrounding child welfare and the rights of the child were coming into conflict with the inviolability of the family unit and ongoing concerns about child delinquency and criminality. The tensions that resulted from seemingly incompatible and contradictory beliefs around the issue of discipline were manifested not only at the social and intra-community levels, but also at the institutional level, within the provinces of government

\footnotetext{
81 'Stratford and Ngaire', Hawera and Normanby Star, 26 October 1895, 4.

82 See Hendrick, 7-12; Scott and Swain, 4; Bronwyn Dalley, Family Matters: Child Welfare in Twentieth Century New Zealand (Auckland University Press, 1998), 15-16.

83 I refer here particularly to the passage of the Neglected and Criminal Children Act 1867 which enabled provincial councils to establish industrial schools in which children, who were judged to be either delinquent or neglected, could be detained. Included in the Act is the ruling that a boy of any age attempting to abscond from an industrial school would receive a 'private whipping' in punishment. Statutes of New Zealand 1867, No. 14, Neglected and Criminal Children's Act, s. 46, 172.

84 Maclean, 15.
} 
and law: government ministers introduced child protection legislation while confidently denying the need for it; the courts, forced to censure some parents for their excessive use of violence, continued to rebuke others for not punishing enough; members of the public were moved to indignation when cases of child cruelty did come to light, yet few were willing to speak up against violence occurring among the families living within their own communities.

The recent twenty-first century debates surrounding child discipline laws, questions of public intervention in cases of suspected abuse, and the policing of private life and families, demonstrate that such tensions remain far from resolved. The defence of reasonable force to correct children's misbehaviour can no longer be used in court, although parents retain the legal right to use force in certain circumstances. In 2009, a government-ordered review found that the new law was working well and, the following year, the New Zealand police reported that the legislative change had had only a minimal impact on their activities. ${ }^{85}$ Nevertheless, the public discussions on child discipline continue. ${ }^{86}$ It is my contention that a clear understanding of the historical antecedents of these issues can only assist in their resolution. It is therefore imperative that new directions continue to be taken in legal historical research by asking hard questions about the private worlds of home and family, and how private behaviours have been codified and moderated by the law.

\footnotetext{
85 Review of New Zealand Police and Child, Youth and Family Policies and Procedures relating to the Crimes (Substituted Section 59) Amendment Act, 1 December 2009, http://yesvote.org.nz/files/2009/12/s59-report-toprime-minister.pdf accessed 10 September 2011; and New Zealand Police, 6th review of Crimes (Substituted s59) Amendment Act 2007, 12 March 2010, http://www.police.govt.nz/news/release/22547.html accessed 10 September 2011.

86 See, for instance, the release of a documentary in July 2011 that challenges the findings of the Government review of the new legislation, http://www.radionz.co.nz/news/national/80224/family-first-challenges-reviewof-child-discipline-laws accessed 10 September 2011.
} 